\title{
Modalităţi lingvistice de adresare convenționale vs neconvenționale. (Formule de salut vechi și noi în limba română)
}

\author{
Daiana Felecan* \\ Facultatea de Litere, Universitatea Tehnică din Cluj-Napoca, Centrul Universitar Nord, Str. Victoriei 76, 430122 Baia Mare, România
}

\section{Despre articol \\ Istoric:}

Primit 30 aprilie 2014

Acceptat 2 iulie 2014

Publicat 13 ianuarie 2015

Cuvinte-cheie: contact lingvistic împrumut lexical psiholingvistică sociolingvistică stilistică

\begin{abstract}
Rezumat
Între mijloacele lingvistice de care uzează indivizii în cadrul procesului comunicativ se înscriu și modalitățile de adresare, iar în cadrul acestora, un rol important revine formulelor de salut.

În prezenta comunicare, ne propunem să identificăm o serie de forme / formule de salut utilizate în spaţiul public românesc actual şi să le analizăm din perspectivă structurală și funcțională (valori pragmatice contextuale). Alături de unitățile consacrate (gramaticalizate / clișeizate), vom înregistra și altele, purtătoare de noi valori semantice, survenite în urma unor determinări situaţionale.

Astfel, vom distinge între două modalități lingvistice de salut: convenționale (neutre din punct de vedere stilistic, utilizate de întreaga comunitate de locutori) și neconvenționale (de import recent, englezești majoritatea, calcuri, care reconstituie tiparul originar sau sînt preluate fără nici o modificare din limba împrumutătoare, utilizate cu intenție persuasivă sau ironică).

Corpusul va fi preluat din internet.

Ca metodologie, ne vom folosi de instrumentarul teoretic de proveniență psihosociolingvistică, pragmatică, etnologică, antropologică.
\end{abstract}

[...] există o competență, un saber care se referă la a vorbi în situații determinate și cu privire la anumite lucruri, cu anumiți interlocutori. Este ceea ce se spune-în sens negativ-cînd constatăm că ceea ce spunem nu corespunde normelor, cînd spunem că sîntem incapabili să scriem o scrisoare de condoleanțe, adică să construim acest fel de text, sau cînd o doamnă ne atrage atenția: „Nu se vorbește așa cu o doamnă!” (Coșeriu, 1992-1993, p. 36)

A nu saluta sau a nu răspunde formulei întemeietoare primite în dar nu este ca și cum ai știrbi ceva din alcătuirea celuilalt, ci este ca și cum te-ai dezice de tine, ca și cum ți-ai extirpa aparatul de umanitate, ca și cum ți-ai blestema părinții. Este ca atunci cînd te încredințezi pradă instinctelor, ca atunci cînd ți se clonează profilul după acela al rinocerilor ionescieni.

\section{Considerații generale}

Debutul oricărui dialog este condiționat de un scenariu verbal ritualizat, de o prefață cu funcție inițiatoare de comunicare. Ne referim la felul în care interlocutorii își întind reciproc punți comunicative. În salut, ca act verbal expresiv preliminar și obligatoriu, limbajul devine tranzitiv, întrucît expresiile proemiale întemeietoare (diferitele variante de salut) spun ceva despre emițător și, totodată, obligă la constituirea în replică a perechii de adiacență: răspunsul la salut. Această formulă autoprezentativă, salutul, este un caz special de utilizare a limbii, în care actul verbal performat, chiar dacă nu se constituie sub formă interogativă (cu excepția salutului de tip întrebare), presupune un răspuns.

*Adresă de corespondență: daiana18felecan@yahoo.com. 
Odată cu diversificarea canalelor de comunicare în societatea contemporană (cel care mijlocește comunicarea prin intermediul computerului deține supremația), se multiplică și posibilitățile de declanşare, menținere și suspendare a contactului verbal cu interlocutorul. În trecerea de la „oralitatea” directă (interacțiunea verbală face-to-face) la „scripturalitatea” indirectă (interacțiunea la distanță, mediată de un suport electronic), comunicarea interindividuală cunoaște un proces de „de-ritualizare”, de ieșire din structuri preformate și tinde să-și contureze un fond autonom de formule adresative, construite simultan prin conservare și inovație.

Modele comportamentale (implicit și cele lingvistice) de prestigiu care s-au infiltrat în spaţiul lingvistic românesc actual și-au marcat teritoriul și în sectorul mijloacelor de adresare, preschimbînd sau combinînd profilul tradiționalizat al modalităților lingvistice consacrate în / cu unul profund atins de trendul alocutiv al limbii donatoare. Felul în care se prezintă astăzi adresarea în limba română este tributar, pe de o parte, avatarurilor sistemului alocutiv tradițional, convențional și convenționalizat, iar pe de altă parte, influențelor (în speță, anglo-americane, dar și de altă proveniență) din limbile cu care româna a intrat în contact.

Formulele de salut se înscriu între expresiile adresative stereotipizate ${ }^{1}$ de care uzează indivizii în cadrul procesului comunicativ.

Ne-am oprit atenția asupra acestui subtip al actelor verbale expresive, deoarece studiul lor permite formularea observațiilor care vizează aspecte ce țin de inițierea, menținerea, eventual, și de încetarea relațiilor interindividuale. Formula de salut este modalitatea prin care locutorul iniţiază și încheie un contract verbal plin de implicații psihosociale cu repercusiuni în poziționarea sa în interiorul comunității ${ }^{2}$.

\section{Obiectivele cercetării}

În prezenta contribuție - parte a unui studiu mai amplu, avînd ca obiect formulele de salut neconvenționale-ne propunem să identificăm o serie de forme / formule de adresare, în spețăa, de salut, utilizate în spațiul public românesc actual și să le analizăm din perspectivă structurală (tehnici de construcție) și funcțională (valori pragmatice contextuale). Alături de unitățile consacrate (gramaticalizate / clișeizate), vom înregistra şi altele recente, purtătoare de noi valori semantice și stilistice, survenite în urma variatelor determinări situaționale. Vom studia structurile verbale de tip salut din româna actuală, considerîndu-le, pe de o parte, forme rituale comunicative, iar pe de altă parte, „ieșiri din ritual”3.

Concret, intenționăm:

- să prezentăm clasa formulelor de salut ca acte de limbaj;

- să stabilim o tipologie în cadrul clasei avute în vedere;

- să analizăm unităţile considerate în cadrul conversației online și face-to-face;

- să formulăm opinii referitoare la specificul formulelor de salut în cultura română;

- să identificăm principalele trăsături ale tipului pragmatic românesc în privința parametrului investigat.

${ }^{1}$ „Un criterio per distinguere le formule di saluto dalle altre formule stereotipiche della comunicazione quotidiana è offerto dall'analisi della tipologia dei turni conversazionali tipicamente riservati al saluto. Mentre gli scambi augurali richiedono come complemento una formula di ringraziamento (buon compleanno / grazie), i saluti ricorrono abitualmente abbinati a coppie adiacenti (adjacency pair) di tipo particolare, fortemente ritualizzate, caratterizzate dalla presenza della formula di saluto sia in prima che in seconda posizione e, almeno prototipicamente, dalla cosiddetta «risposta-eco», vale a dire della ripetizione come complemento preferenziale non marcato della stessa forma presente nel primo elemento (tipo ciao / ciao). Nella realtà della comunicazione quotidiana sono tuttavia pochi i saluti effettivemente realizzati con coppie adiacenti canoniche, ed esistono comunque alcune formule difficilmente classificabili nell'ambito esclusivo dei saluti o degli auguri, come buona notte, che prevede tanto un complemento-eco quanto la risposta Grazie, anche a te, tipica invece degli scambi augurali” (Pietrini, 2010, p. 238-239).

${ }^{2}$ „Lo stretto legame esistente tra le formule di saluto e la struttura sociale della comunità che le esprime, con la sua gerarchia di valori, i suoi stereotipi culturali ed i suoi schemi concettuali, rende pertanto possibile dedurre dalla scelta delle formule di saluto impiegate indicazioni significative sul tipo di rapporto sociale e personale che esiste tra i partecipanti all'interazione" (Pietrini, 2010, p. 235).

${ }^{3}$ Sintagma este preluată de la Hobjilă (2008). 
Corpusul este extras din internet.

Ca metodologie pentru decodarea corectă a funcțiilor salutului verbal, vom folosi instrumentarul teoretic specific analizei discursului, psihosociolingvisticii, pragmaticii, semioticii, etnologiei, antropologiei. Actele verbale de tip salut investigate sînt fapte lingvistice realizate la nivelul individual al limbajului. Dintre acestea, unele sînt frecvent utilizate de un număr mare de vorbitori; astfel, ele încetează să mai fie fapte de vorbire și intră în sistemul limbii, trecînd în nivelul universal al limbajuluí .

Se disting două categorii de saluturi verbale:

- convenționale (consacrate, neutre din punct de vedere stilistic, recunoscute / utilizate de întreaga comunitate de locutori) și

- neconvenționale (de import recent, englezești majoritatea, calcuri, ce reconstituie tiparul originar sau sînt preluate fără nici o modificare din limba împrumutătoare, și inovații).

\section{Sistemul adresativ în limba română}

Adresarea reprezintă o modalitate specifică de raportare a locutorului la alocutor în cadrul procesului comunicativ. Relația dintre cei doi actanți ai comunicării se poate institui fie exclusiv la nivel lingvistic, fie (și) la nivel nonlingvistic sau paralingvistic.

Adresarea

- presupune două operații fundamentale: „desemnarea destinatarului prin forme nominale sau pronominale și solicitarea acestuia să-și asume un asemenea rol, prin folosirea vocativului (cu intonație specifică) și / sau prin forma imperativă a enunțurilor” (DSL, s.v., p. 27) și

- se realizează în planul vorbirii printr-un ansamblu de termeni și expresii puternic ritualizate / standardizate: „Ces expressions ont très généralement, en plus de leur valeur déictique (exprimer la «deuxième personne», c'est-à-dire référer au destinataire du message), une valeur relationnelle, servant à établir entre les interlocuteurs un certain type de lien socio-affectif (dans une conception étendue de la déixis, on dira que ces expressions relèvent à la fois de la «déixis personnelle» et de la «déixis sociale»" (Charaudeau \& Maingueneau, 2002, p. 30).

Mijloacele lingvistice utilizate pentru realizarea actului adresării sînt repartizate în două categorii (vezi Charaudeau \& Maingueneau, 2002, p. 30; DSL, p. 27):

a) substantive sau substitute (adjective și numerale cu uz substantival): nume proprii (prenume, nume de familie, porecle, diminutive etc.) și nume comune (numele generice de persoane: domn, doamnă, femeie, băiat etc.; numele generice de rudenie (mamă, tată etc.); numele de relaţii interpersonale (coleg, $-\breve{a}$, vecin, $-\breve{a}$ etc.); nume de titluri, funcții, profesii (director, decan, ministru etc.); nume calificative sau evaluative (mincinos, leneş, viclean, harnic etc.); termeni afectuoși sau injurioși, în vocativ (prostule, dragule, drace, zîno etc.);

b) pronume. Româna posedă o paradigmă foarte generoasă a pronumelor de adresare politicoasă ${ }^{5}$. Există,

${ }^{4}$ Pentru discuția referitoare la nivelurile limbajului, vezi Coșeriu (1992-1993, p. 27-47).

${ }^{5}$ „Auzul îmi este adeseori «zgîriat» de unele forme de adresare pe care le aud pe la televizor, de lipsa de respect pe care unele modalităţi de a vorbi despre alții / cu alții le implică. Astfel, uneori, diverşi realizatori de emisiuni, «se trag de şireturi» cu personalități marcante, cu persoane în vîrstă, în fine, cu persoane cu care / despre care ar trebui să vorbească mai politicos, respectînd atît tradiția poporului român, cît şi limba română, care pune la dispoziție mijloace de exprimare a politeții atît de bogate. [...] Politețea medie este o trăsătură a limbii române care permite o nuanțare a vorbirii inexistentă în alte limbi şi de care ar trebui să ne folosim atunci cînd simţim impetuoasa nevoie de a ne «trage de şireturi» cu persoane mai în vîrstă, superioare în rang / funcție etc. [...] Această bogăție formală a pronumelui de politețe, dezvoltarea lui prodigioasă—nuanțarea pe grade de politețe, menținerea în limbă a formelor vechi («domnia sa ») în paralel cu formele noi rezultate din acestea («dumneasa ») —constituie dovezi ale vechimii şi importanței sale în limba română, reflectînd mentalitatea şi psihologia poporului român, atitudinile şi modelele de comportament ale acestuia, consolidate într-un timp îndelungat. Modelele psihosociale şi comportamentale ale românilor constituie fondul bogat care susține forma-forma pronumelui personal de politețe, dar şi alte forme de exprimare a reverenței (adresări cu «doamnă / domnule», «mamă-soacră », «domnule inginer» în loc de «domnule X» etc.). Or, ce se întîmplă azi? Pe acest fond-profund înrădăcinat, poate la fel de vechi ca poporul român—se încearcă suprapunerea unei forme superficiale, o formă calchiată după modele străine, care au fost create pe alt fond. Este vorba, fireşte, despre modelul 
astfel, trei modalități gramaticale de realizare a adresării: familiaritatea (prin $t u$, pronume personal de persoana a II-a singular + verbul la persoana a II-a singular), politețea medie (prin dumneata, pronume personal de politețe + verbul la persoana a II-a singular) şi politețea absolută (dumneavoastră, pronume de politețe + verbul la persoana a II-a plural).

Principiile care prezidează alegerea unuia sau a altuia dintre elementele din sistemul termenilor de adresare în limba română sînt în conformitate cu anumite variabile: „statutul social și relaţiile de rol dintre interlocutori (termeni protocolari de adresare vs. termeni familiari” (Manu Magda, 2010); statutul socioprofesional (nume de funcții, ocupații, titluri); „factorul vîrstă este, de obicei, marcat prin utilizarea unor formule de adresare $+/$ - reverențioase (literar: domnule, doamnă; familiar: nene, unchiule, tanti, tataie, mamaie, șefule, șefă etc. sau regional: babule, bade, dodă, gagă, lele, leliţă, lițăa, mătuşă etc.), asociate cu pronumele corespunzătoare relației + / - egalitate între interlocutori (tu, dumneata, mata, matale, tale, tălică) (ibidem); variații ale numelor gradelor de rudenie conferite în adresarea familiară din comunități diferențiate din punct de vedere diastratic.

În funcție de gradul de formalitate a contextului comunicațional, selecția formulelor de adresare se operează astfel:

a) „în situații informale, marcate prin intimitate, sînt utilizaţi termeni familiari de adresare-vocativele numelor proprii sau ale substantivelor comune și formele verbale de persoana a II-a singular” (ibidem);

b) „situațiilor formale, caracterizate prin distanță socială și diferențe pertinente de statut social, le corespund formule de adresare mai complexe (formule protocolare de adresare), asociate cu forme verbale de persoana a II-a plural" (ibidem).

Totodată, alegerea vocativelor și a alocutivelor pronominale se face în funcție de rațiuni ce țin de simetria / asimetria relațiilor interpersonale.

\section{Salutul - subtip adresativ al actelor verbale expresive}

\subsection{Delimitarea conceptului}

În literatura de specialitate românească nu există pînă la această dată un studiu care să fi tratat salutul în perspectiva propusă de noi. Dispunem de o lucrare din 1984 (Pietreanu) și de cîteva articole sporadice (vezi bibliografia), care abordează formulele de salut tradiţionale, alocînd un spațiu restrîns noilor modalități adresative și funcțiilor îndeplinite de acestea în comunicare.

Avînd în vedere mecanismele pragmatice implicate în structura actului de limbaj de tip salut, acestuia i-au fost conferite diverse definiții. Astfel, salutul este:

american. Despre națiunea americană putem spune că «s-a născut democrată ». Sistemul democratic american permite un «joc» social—sus-jos—caracterizat de variabilitate, mobilitate pe scara succesului (social, economic, politic), deci, raporturi sociale şi interumane instabile în toate păturile sociale, în toate categoriile socio-profesionale, raporturi care se pot schimba peste noapte (bogătaş > falit, cineva > nimeni). Aceste aspecte se reflectă, desigur, în comportament, în atitudinea față de ceilalți şi implicit în limbaj. [...] Fondul pe care s-a creat sistemul reverențial englezesc (american) este deci profund diferit față de cel românesc, care s-a creat într-un sistem mai puțin mobil şi tributar Orientului, un sistem în care expectanța reverenței este mai mare, un sistem aflat la granița dintre modelul castelor orientale (vezi sistemul politic românesc, mobil doar pe orizontală, nu şi pe verticală) şi modelul democratic occidental (care acționează mai mult în domeniul cultural-artistic). Se adaugă aici sărăciavrem, nu vrem, caracteristică poporului român—care a facilitat traiul în comun (apropierea este firească, nu căutată, forțată), deci şi delimitarea exactă a celor apropiați (familie, prieteni, vecini) de ceilalți, față de care s-a nuanțat adresarea: politețe medie (față de persoane egale), politețe maximă (față de persoane superioare în rang / funcție). Aşadar, alte relații interumane, alte modalități de exprimare a politeții. Ceea ce se întîmplă în mass-media românească—adoptarea unor forme străine pe fondul autohton profund diferit—este nu numai nepotrivit, ci şi de-a dreptul ridicol. Ridicol pentru unii «nimeni» care se pun pe plan de egalitate cu personalități marcante, cu persoane cărunte cărora le-ar putea fi nepoți, neînțelegînd-sau neacceptîndfaptul că bunul-simț al poporului român nu acceptă această egalitate. Sau pur şi simplu mergînd «cu valul», valul ce ne poartă pe toți spre vest... [...] De ce oare respectarea fondului autohton existent la noi şi a bunului-simț popular trebuie să treacă în desuetudine? De ce trebuie să imităm papagaliceşte modele străine, mereu şi mereu? Pentru numele lui Dumnezeu, de ce să nu fim şi DIFERIȚI? De ce să absorbim fără discernămînt modele vestice fără nici o legătură cu identitatea psihologică şi morală autohtonă? De ce să evităm modelele proprii de exprimare / adresare şi vorbirea neaoş românească aferentă acestora? De ce ne ferim de identitatea noastră profundă” (Andrei, 2005). 
- comportament comunicativ, prin care vorbitorul își arată disponibilitatea faţă de interlocutor;

- „comportament comunicativ deliberat, care se exprimă prin procedee lingvistice consacrate de vorbirea uzuală și care sînt semnificative pentru normele socioculturale ale politeții” (Pietreanu, 1984, p. 8);

- „comportamentul comunicațional, gestual sau verbal (ori și gestual și verbal), cu o semnificație cunoscută unui micro- sau macrogrup social, prin care se dă un semn de atenție, de respect, de politețe unei persoane sau unui grup" (Pietreanu, 1984, p. 29);

- "parola o gesto d' affetto, simpatia o deferenza, spesso di carattere formale, rivolti a una persona quando la si incontra o ci si accomiata" (Sabatini \& Coletti, 2005);

- „o modalitate de manifestare a interesului și a bunăvoinței față de receptor sau a surprizei de a-l întîlni” (Necula, 2012, p. 7);

- un „act expresiv de natură inițiativă”, urmat de un alt act de salut reactiv sau consecutiv, intrînd într-un raport de complementaritate structurală cu actul precedent (vezi Necula, 2012, p. 10).

Din punctul de vedere al momentului adresării salutului, acest act de limbaj nu cunoaşte o localizare unică în perimetrul unei secvențe verbale, el putînd sta la începutul, în interiorul sau la sfîrșitul acesteia.

\subsection{Salutul verbal, ca act autoprezentativ}

Salutul verbal este unitate definitorie a interacțiunii, fiind un act de limbaj cu deschidere / ancorare înspre interlocutor. Actul de tip salut îndeplinește, în mod prototipic, o funcție rituală (asigură conformitatea cu maximele principiului politeții) și strategică (garantează coeziunea discursivă prin anularea hiatusurilor interacționale) (cf. și DSL, s.v. act, p. 17-18).

Salutul este un act ilocuționar „realizat prin utilizarea limbii în situații de comunicare concrete” (DSL, s.v. act, p. 18), care „asociază conținutului propozițional al unui enunț o forță convențională specifică, determinată de intențiile comunicative ale emițătorului” (DSL, s.v. ilocuţionar, p. 256), susceptibil de a comporta o valoare de adevăr (deci constatativ, vezi DSL, s.v. constatativ, p. 135) și, totodată, potențial performativ (cu realizare reușită sau nereușită prin raportare la competența de decodare a destinatarului) (vezi Austin, 2005 și Searle, 1972-teoria actelor de limbaj).

Salutul verbal intră în clasa actelor expresive (vezi Proost, 2009, p. 997; Degand, 2009, p. 1013) (prin intenția asociată de locutor actului ilocuționar performat, acesta din urmă exprimă „o anumită stare psihologică sau atitudine, determinată de o proprietate sau o acțiune a emițătorului sau a receptorului”, DSL, s.v. ilocuționar, p. 256).

În cercetarea de față am pornit de la constatarea deplasării unor modalități de salut specifice registrelor comunicative informale înspre limba română standard (i.e., abandonarea poziției din uz în favoarea celei din sistem, fapt care atrage noi valorizări stilistice), consecință a permutării valorilor din România posttotalitară. Alături de alte expresii verbale colocviale ale deixisului social, formulele de salut au rolul de a semnala orientarea locutorului către alocutor în româna actuală. În această calitate, ele funcționează ca indici de alocutivitate („mărci lingvistice ale funcției conative (de apel) și ale funcției fatice (de menținere a contactului între interlocutori), reprezentînd dovezi ale atenției pe care interlocutorii și-o acordă unul altuia pe durata interacțiunii”, Manu Magda, 2009, p. 459-460).

Principala funcție pe care formulele de salut o exercită în comunicare este autoprezentarea lingvistică. Prezentarea „est l'opération linguistique qui correspond à l'intention de déterminer le mode d'existence d'un être (ou d'un processus)" (Charaudeau, 1992, p. 302). Prin mijlocirea formulelor de salut, locutorul își formulează intenția de determinare a propriului mod de a fi prin raportare la interlocutor (componenta constatativă / descriptivă a actului verbal formulat) și, totodată, pune în acțiune / face manifestă această intenție, sincronizînd actul enunțării cu performarea / punerea în trăire a conținutului propozițional performat (componenta performativă).

În analiza ulterioară vom arăta cum unele dintre unitățile de analiză avute în vedere se revendică de la alte resorturi pragmatice decît acelea definitorii pentru o societate (cum se pretinde a fi și societatea românească) definită de principiul recunoașterii și împărtășirii cutumelor referitoare la relațiile de rol ierarhic 
organizate (în care criteriul de referință în selecția formulelor de salut este adecvarea la / pertinența cu (vezi Sperber \& Wilson, 1996-teoria pertinenței) situația socială în care locutorul se află față de interlocutor).

Așadar, salutul este un act verbal prezentativ autoreflexiv prin care locutorul exprimă o intenție de acord I dezacord cu prescripțiile codului politeții pragmatice, specifice comunității lingvistice considerate.

\subsection{Funcţii lingvistice și pragmatice}

Salutul îndeplinește diverse funcții în cadrul procesului comunicativ:

- funcția conativă: lansarea unei provocări perlocuționare la dialog partenerului (,interpellation et désignation de l'interlocuteur, marquage de fin d'un tour de parole et désignation du «successeur», marquage de la relation, etc." (Charaudeau \& Maingueneau, 2002, p. 31);

- funcția fatică: în cadrul dialogului la distanță / mediat, în condițiile întreruperii temporare a acestuia, locutorul poate (re)formula alte expresii verbale cu rol de salut cu scopul de a verifica interesul alocutorului în vederea continuării dialogului;

- funcția metalingvistică: locutorul precizează / numește, folosindu-se de un verb performativ explicit, cu sau fără acuzativul beneficiarului, actul de a saluta prin enunțuri de tipul: „(Te) salut.” ${ }^{6}$, „Te-am salutat." (secvențe care pot funcționa ca formule de salut propriu-zise);

- funcția de a numi (identificatoare): atunci cînd se întîlnesc sau se despart, interlocutorii nu sînt obligați să-și spună pe nume, însă se cuvine să se salute; felul în care salută devine semn distinctiv pentru enunţiator;

- funcția socială: salutul are rol integrator din punct de vedere social. Există comunități rurale (astăzi tot mai puține ca urmare a extinderii urbanizării) în care localnicii îi salută pe necunoscuți.

\subsection{Semnificația condiționată cultural a salutului}

4.4.1. Selecția posibilităților oferite de sistemul alocutiv dintr-o limbă se face în conformitate cu convențiile socioculturale ale spațiului lingvistic respectiv ${ }^{7}$, variind de la un teritoriu lingvistic la altul în funcție de bogăţia inventarului de forme adresative de care dispune.

Ca act verbal expresiv, salutul se impune a fi discutat din perspectivă pragma- și sociolingvistică. Pe lîngă componenta strict informativă pe care o degajă, salutul actualizează încă o componentă—purtătoarea forței ilocuționare a enunțului respectiv—, și anume cea afectivă. În utilizare, se pot identifica situații în care conținutul propozițional al salutului performat nu se suprapune peste intenția emițătorului. Cazul este specific saluturilor condiționate contextual (vezi, mai ales, situațiile formale de comunicare, ce impun respectarea unui protocol al salutului), numite aici saluturi de conformitate, adecvarea la situație determinînd suspendarea oricărei atitudini afective. Din această perspectivă, salutul este un suport verbal pe baza căruia sînt transmise sentimente sincere sau disimulate.

Condițiile de reușită a salutului sînt garantate numai dacă alocutorul are abilitatea să decodifice corect mesajul formulat de destinator (dacă îl validează conform așteptărilor acestuia).

4.4.2. În cultura română, la fel ca în alte culturi, salutul funcționează ca expresie verbală ce concentrează un modus vivendi al celui care îl performează. În salut sînt depozitate cunoștințele enciclopedice ale locutorului, istoria conversațională a interactanților, predispoziția lor momentană. O persoană care nu salută este sancționată de comunitate prin sentințe definitive, precum: „Nu are cei 7 ani de acasă.”, „Bună ziua, căciulă, că stăpînul n-are gură!" etc. Cel care nu salută sau nu răspunde la salut este stigmatizat drept un individ rudimentar, needucat / infatuat. Lipsa de preocupare a unora dintre locutorii actuali pentru

\footnotetext{
${ }^{6}$ Am întîlnit răspunsul: „Îți faci datoria."

${ }^{7}$ „Sentimentul de simpatie sau respect, din punct de vedere psihologic, este asemănător sau poate chiar identic la toți oamenii, dar expresia lui exterioară este determinată de modelele culturale de comportare” (Pietreanu, 1984, p. 16). „[...] formulele de salut sînt selectate după reguli sociolingvistice, care dictează folosirea termenilor considerați adecvați atît pentru statutul interlocutorului, cît şi pentru situația concretă de comunicare. Salutul, ca formă de comunicare, redă specificul situației, dar şi specificul culturii, al aptitudinilor obişnuite, stereotipe, care sînt greu de decodificat pentru un interlocutor neavizat” (Cojocari, 2008).
} 
îndeplinirea ritualului de a saluta se înregistrează tot mai pregnant atît în conversația orală, cît și în cea scrisă (electronică) ${ }^{8}$. Non-salutul devine tot mai mult o formă de salut, deoarece exercitarea practicii de a saluta este înțeleasă drept o umilință. Oferim, spre exemplificare, două opinii divergente, referitoare la lipsa de obligativitate a / obligativitatea salutului în zilele noastre, decupate dintr-un dialog aflat pe un forum de discuții online:

A. - Nu mi se pare atît de important salutul. De multe ori „uit” să mai salut și foarte des mi se atrage atenția asupra acestui lucru, ceea ce mă cam deranjează, pentru că nu consider că sînt obligat să salut, așa cum nu sînt nici obligat să răspund. Însă salutul cu „servus” este un obicei de pe vremea romanilor, cînd sclavii erau obligați să-și salute stăpînul cu „servus" (sînt sclavul tău), pentru a-și arăta supunerea față de stăpîn [...].

Eunu salut cu servusmai ales pe cei, superiori" mie, darnicipe cei cu care mă aflu aproximativ la același nivel sau mai jos, pentru că eu nu sînt sluga nimănui. Mai spun însă „servus” copiilor mici din fața blocului, care mă salută cu „sărumîna”.

B. - Păi, unde e respectul dacă nu saluți pe cunoscuți și unde sînt educația și respectul dacă nu răspunzi la salut? [...]

A. - Eu cred că-n primul rînd ar trebui să arătăm ce înțelege fiecare prin respect și prin educație (le-am definit de multe ori pînă acum, dar nu mă deranjează să repet). In al doilea rînd, salutul este o obligație?!! (În cazul ăsta, scuză-mă, dar respectul inseamnă supunere, iar eu nu pot fi de acord cu această semnificație, chiar dacă majoritatea înțeleg prin respect acest lucru (adică supunere)). Eu consider că respect înseamnă, totuşi, egalitate, iar printr-o educație (nu dresare) bazată pe convingere (nu pe impunere) se poate cultiva o astfel de atitudine de respect! [...]

B. - Da, salutul e o obligație! Cînd treci pe lîngă un cunoscut, îl tratezi cu respect cînd îl saluți. Dacă treci aşa, ca pe lîngă un panou publicitar, unde e respectul? Ce, dacă zici „bună ziua" înseamnă că nu sînteți egali? Că unul e supusul celuilalt? Deci tu nu ai convingerea că respectul înseamnă a trata pe cel din fața ta cu considerația cu care te tratează și el. [online]

4.4.3. Salutul neutru, impus de tiparele comportamentale din perioada comunistă, pe de o parte, și anularea oricărui cod deontologic în ce privește necesitatea performării lui în epoca postdecembristă, pe de altă parte, sînt extremele care au generat situaţia din româna actuală.

Dacă în perioada totalitară interacțiunea verbală se construia în respectul relaţiilor interindividuale ierarhice, situație cu repercusiuni în adecvarea adresativă contextuală, după căderea comunismului și eliberarea limbii de sub canoanele cenzurii, se înregistrează o relaxare tot mai accentuată a discursului în ce privește construcția modalităţilor de abordare verbală interumană.

Deferența, ca model constitutiv al raporturilor interlocuționare prerevoluționare, este destituită de familiaritatea, destinderea, democratizarea strategiilor intercomunicative. Locul rigorii discursului profesionalizat, de lemn, antedecembrist a fost luat de textul relaxat (oral sau scris), eliberat de orice constrîngeri formale, de-contextualizat (conceput fără a se mai ține cont de adecvarea la situația de comunicare) și eterogen (mixtură de modele autohtone și adoptări de import recent). (Pentru o descriere a mecanismelor şi practicilor de comunicare sociale actuale, cf. și Magda, 2004, p. 255-278 şi Magda, 2007, p. 62-101). Distanța socială impusă altădată de asimetria rolurilor sociale și de contextele comunicaționale formale

\footnotetext{
${ }^{8}$ Principalele reguli ale salutului la români sînt: „se cuvine ca bărbații să salute femeile, tinerii pe cei vîrstnici, subalternii pe superiori, noii-veniți pe cei prezenți într-un anumit loc, cel care merge pe cel care stă. Persoanele necunoscute se pot saluta îndeosebi atunci cînd se urmărește stabilirea unui contact social, contact care este posibil între orice fel de persoane, deci și între necunoscuți. Politețea cere să salutăm persoanele necunoscute atunci cînd intrăm într-o instituție (întreprindere), într-un birou, într-un compartiment de tren sau în lift, într-un magazin mic etc. Nu se salută însă persoanele necunoscute într-un magazin mare, într-o gară, într-un oficiu poștal, într-un autobuz ori într-un tramvai. Într-un oraș, persoanele necunoscute nu se salută, spre deosebire de oamenii dintr-un sat, care se salută chiar dacă nu se cunosc (bine). Dacă salutul se adresează unui grup, nu este obligatoriu să se dea mîna cu fiecare; dacă totuși se dă mîna, este recomandabil să se înceapă cu persoanele cărora li se cuvinte mai mult respect (superiori, persoane în vîrstă, femei etc.). Cînd grupul e foarte numeros, se poate renunța la strîngerea mînii, efectuîndu-se numai salutul verbal, însoțit sau nu, de ușoara înclinare a capului și a corpului” (Pietreanu, 1984, p. 17-18).
} 
este redusă considerabil sau ștearsă de proximitatea familiară instaurată în urma coborîrii barierelor sociale și, mai ales, morale, mișcare înregistrată odată cu dispariția regimului totalitar. Ne adresăm tot mai apăsat într-o română anglo-americanizată, cultivăm un respect al solidarității de gașcă, al de-convenționalizării convenționalului, al camaraderiei în varianta amiciţiei balcanice ${ }^{9}$. Termenii de adresare consacrați sînt repudiați cu bună știință în virtutea unei epidemii verbale de tutuială ${ }^{10}$ greșit gestionată; ne vorbim de la egal la egal indiferent de context sau de statut social. Din acest punct de vedere, româna de astăzi a devenit un spațiu al inadecvării ${ }^{11}$, al improvizației, în care fiecare simte că are dreptul să-l interpeleze pe celălalt conform legii bunului plac, însă, paradoxal, nimeni nu se înțelege cu nimeni și orice tentativă de dialog social eșuează inevitabil în polemică.

Pe de o parte, media autohtonă, simțindu-se în drept să pună orice cuviință sub semnul îndoielii (chiar și utilitatea respectului reciproc), și, pe de altă parte, importul neadecvat de modele comportamentale verbale străine de spiritul etnic și moral național, izvorîte din graba de a ne înscrie în trendul vest-european și transatlantic, au dus la apariția unui repertoriu bibrid de practici și formule verbale. Vorbim, implicit ne salutăm într-o limbă în care uzul face norma, iar uzul merge pînă la a ignora practica bunului-simț de a saluta (vezi lipsa de politețe de care a dat dovadă, în repetate situații formale de comunicare, președintele României, Traian Băsescu, prin refuzul de a da mîna cu anumite persoane publice) ${ }^{12}$ :

\section{Președintele Traian Băsescu nu a dat mîna cu Gabriel Oprea, Radu Stroe și Relu Fenechiu la ceremonia depunerii jurămîntului de la Cotroceni.}

\footnotetext{
${ }^{9}$ Pentru conotația termenului balcanic, vezi Felecan (2013).

${ }^{10}$ Un diagnostic corect, pus societății românești actuale privite din perspectiva pierderii aptitudinii de a dialoga civilizat, se găsește în următoarea descriere: „Tutuiala e la modă. E semnul cordialității de gașcă, al democrației victorioase, al sociabilității «americane». [...] Dovedim astfel că sîntem «branșați», actuali, globalizați. [...] Ne tutuim. Suntem de-o teapă. Prieteni. Ne-am născut ieri. [...] «Dumneavoastră » se spune numai în bășcălie, numai cînd vrei să-ți exprimi antipatia, neîncrederea, disprețul. «Normală» e doar tutuiala. [...] cînd te poți tutui cu oricine, cînd tutuiala devine o deprindere curentă, prestigiul și miracolul tandru sau camaraderesc al lui «tu» se degradează. În mod normal, la «tu» trebuie să ajungi; printr-o delicată chimie a afectelor, printr-un răbdător spor de încredere și printr-o reciproc consfințită afinitate. «Tu» este un mod de a reformulaîn condiții de intimitate—instituția respectului. Dimpotrivă, inflația tutuielii instituie indiferența, stereotipia, griul. Spațiul dintre oameni devine monoton, ierarhiile se șterg, nuanțele sufletești ale comunicării devin irelevante. [...]

Din cînd în cînd, mi se pare că o mulțime din relele cotidiene sînt rezultatul unei proaste administrări a tutuielii, efectul exceselor ei. Guvernanții îi tutuiesc cu autoritară nonșalanță pe gazetari, gazetarii îi tutuiesc sprințar pe guvernanți, miniștrii tutuiesc instituțiile, instituțiile îi tutuiesc pe cetățeni, cetățenii se tutuiesc între ei și toți laolaltă ne tutuim cu Europa. Diferențele, demnitățile, eticheta, protocolul—sînt demodate. Ne scufundăm în omogenitatea lui «tu», iar «tu» evoluează semantic spre «nimeni». Nu ne-ar strica un pic de ștaif. Nu ne-ar prinde rău o scurtă epidemie de politețe” (Pleșu, 2006, p. 77-79).

${ }^{11}$ În performarea actelor expresive, implicit a salutului, limba română manifestă conservatorism în ce privește recunoașterea polului care deține puterea discursivă și respectarea distanței sociale: „[...] în cultura română obligativitatea și prioritatea în inițierea acestui act îi revine, de regulă, vorbitorului cu statut inferior. Mai mult decît atît, acesta alege formulele de salut adaptîndu-le la identitatea destinatarului, pentru a marca în primul rînd diferențele de vîrstă și de statut social (si, uneori, chiar diferențele de gen). Sensibilitatea vorbitorilor români la parametrul puterii discursive și al distanței sociale se reflectă și în comportamentul locutorului cu statut dominant. Acesta poate să încurajeze diminuarea distanțelor în comunicare și să manifeste disponibilitatea de a negocia relația interpersonală în favoarea alocutorului cu statut inferior, alegînd să răspundă printr-o formulă de salut asimetrică, eventual din registrul colocvial” (Necula, 2012, p. 14).

${ }^{12}$ Despre tendința de substituire a salutului gestual cu cel verbal vorbește și Nienhaus (2009): „La trasformazione di alcuni gesti in formule verbali non significa una tendenza generale di riduzione del saluto alla parola. Le fasi iniziali e quelle conclusive dell'atto comunicativo sono, invece, caratterizzate da un impatto della gestualità e della presentazione esterna degli interlocutori ancora più forte rispetto alle sue parti centrali. Quando incontriamo una persona, normalmente la nostra prima impressione riguarda il suo aspetto esteriore: la mimica, il gesto, il portamento e i vestiti. La dominanza della vista nella percezione della realtà determina l'impatto iniziale con un'altra persona. Nei contesti della comunicazione interculturale che sono condizionati dal giudizio sull'efficacia dell'interazione, si tende a ritualizzare e normalizzare questi aspetti. Non è un caso che, di fronte ad una tendenziale riduzione di formalità, nel mondo dall'alta finanza, del commercio e della politica, si presti grande attenzione alla prima impressione che si potrebbe provocare all'inizio di una trattativa ecc. A parte i militari e altri pubblici funzionari simili, oggi sono forse soltanto i «banker» (e parzialmente i politici) ad accettare la «divisa (vestito scuro, portamento controllato, sorriso obbligatorio ecc.). La riduzione della presentazione individuale segue ovviamente l'intenzione di ridurre il rischio di fare «una brutta figura» a partire dal primo contatto visivo, in compenso si espone a quello dell'appiattimento verso una grigia uniformità".
} 
Președintele Băsescu a dat mîna cu premierul Victor Ponta și cu vicepremierul Liviu Dragnea, după ce aceștia au depus jurămîntul.

Ulterior, vicepremierul Gabriel Oprea a depus jurămîntul. Acesta s-a îndreptat apoi sprepreședintele Băsescu pentru a-i înmîna jurămîntul semnat, aşa cum este protocolul. Oprea i-a dat documentul președintelui, acesta l-a luat, nici unul neschițînd gestul de a da mîna.

Președintele Băsescu nu a dat mîna nici cu miniștrii Radu Stroe și Relu Fenechiu [online].

Liderul PRM a declarat după ceremonia la care europarlamentarii aleși duminică au primit certificatele de reprezentanți ai României în PE, întrebat cum comentează faptul că şeful statului a refuzat să dea mîna cu el, că Băsescu „nu are cultura civilizației” [online].

Foștii preşedinți Ion Iliescu şi Emil Constantinescu au participat, astăzi, la Cotroceni, la ceremonia de aniversare a zece ani de la invitarea României pentru aderarea la NATO. [...]

Ultima dată cînd cei trei au apărut în aceeaşi poză împreună a fost în 1 decembrie 2009, dar atunci

Traian Băsescu a evitat să dea mîna cu Ion Iliescu şi Emil Constantinescu [online].

Ministrul Afacerilor Externe, Andrei Marga, a avut parte de o primire cel puțin ostilă din partea preşedintelui Traian Băsescu, la Cotroceni. După depunerea jurămîntului, Marga s-a îndreptat către şeful statului pentru a-i da mîna, moment în care acesta a ezitat. I-a aruncat, în schimb, cîteva vorbe dure, după mimica pe care au surprins-o camerele de fllmat, apoi i-a strîns mîna fugitiv, de protocol [online].

4.4.4. Prefață și epilog al oricărui dialog standardizat, salutul transmite informații, pe de o parte, despre statutul psihologic și social al locutorului, iar pe de altă parte, despre contextul comunicaţional. Constituit pe modelul comportamentului verbal euristic (vezi GALR, p. 834), salutul are funcție structurală în dialog, perechea de adiacență salut - răspuns la salut reprezentînd modul de organizare a discursului: „What the first party says both conditions and creates an expectation for what the second party will say" (Duranti, 1997, p. 245).

Salutul este, în ultimă instanţă, actul verbal prin care locutorul face dovada gradului de educaţie morală, socială și intelectuală de care dispune. Premisele dialogului sînt anunțate de felul în care salutăm sau sîntem salutați. Salutul este un comportament comunicativ condiționat cultural, fiind reglementat de diferențele specifice fiecărei națiuni în parte. Indiferent de parametrii în funcție de care îi sînt delimitate modalitățile de manifestare, nu există cultură în care indivizii să nu-și prefațeze contactul verbal (dialogul propriu-zis) sau să nu-și marcheze verbal sau gestual întîlnirea cu celălalt.

\section{Formula de salut}

Formula de salut este, potrivit unei abordări tradiționale, „o formulă de politețe, consacrată prin uz, deci o formă convențională de exprimare verbală a adresării reverențioase” (Pietreanu, 1984, p. 83).

Formula de salut, ca expresie a comportamentului comunicativ de tip salut, reprezintă un enunt sau grupuri de enunțuri prin care se exprimă actul de salut și care are / au drept scop transmiterea unor atitudinicu valoare psihosocială. Formulele de salut sînt, alături de alți termeni de adresare, elemente lexicale utilizate pentru exprimarea politicoasă.

Formulele de salut consacrate sînt structuri lingvistice clișeizate, stereotipizate, pietrificate, fixate prin uz repetat, determinate de comportamentul sociocultural al locutorilor în situațiile variate ale comunicării.

Atitudinea lingvistică a vorbitorilor în actul verbal de tip salut este prin excelență pragmatică, de vreme ce ei operează o selecție stilistică între posibilităţile oferite de sistem: locutorii nu creează neapărat modalități adresative noi ${ }^{13}$, ci de-construiesc și apoi re-constituie sau re-construiesc formule de salut pe baza unor fundamente existente în fondul lingvistic: „[... [în actul de salut nu putem vorbi de o creație în sensul de

\footnotetext{
${ }^{13}$ „Domeniul formulelor de salut e probabil mai dinamic decît se crede de obicei, dar vorbitorii înşişi îi percep mai greu transformările: pentru că elementele de bază se conservă, iar cele care nu mai sînt la modă nu dispar imediat. Ca şi în cazul numelor de persoană, moda decide frecvența de uz, dar nu elimină definitiv din limbă nimic” (Zafiu, 2003).
} 
«inovație» lingvistică, ci de o imitație funcțională [...]. Nu este o imitare pasivă a modelelor și formulelor lingvistice, ci o folosire în funcție de intențiile comunicative ale fiecărui vorbitor” (Pietreanu, 1984, p. 44).

Actualizarea formulelor de salut ${ }^{14}$ este influențată într-o măsură variabilă de coordonate obiective și subiective, precum:

- momentul temporal în care se desfășoară interacțiunea (dimineaţă, miezul zilei, seară);

- intervalul de timp în care locutorii nu au comunicat;

- vîrsta și sexul locutorilor;

- numărul participanților la interacțiune;

- statutul socioprofesional al participanților la actul intercomunicativ;

- specificul raporturilor sociale dintre interlocutori;

- gradul de formalitate / semiformalitate / informalitate a interacțiunii;

- nivelul de distanță / familiaritate a relațiilor interpersonale.

\subsection{Algoritmul pragmatic al formulelor de salut}

Reprezentînd un act de limbaj puternic ritualizat și stereotip, deschis și potențial, salutul verbal urmărește provocarea unei reacții verbale / nonverbale din partea destinatarului. Conceput constitutiv bimembru, salutul impune, așadar, ocurența unei perechi de adiacență, redînd intenția de ancorare a eului locutorului în celălalt și presupune confirmarea de primire a ofertei printr-o achitare a datoriei de către interlocutor. Acesta din urmă nu poate rămîne indiferent față de emițător, ci trebuie să-și manifeste gratitudinea prin întoarcerea cu un tip de „cadou verbal” de aceeași factură: „In this way, participants continually display their awareness of how their use of language contributes to the constitution of the social event they are engaged in" (Bublitz, 2009, p. 891-892).

Salutul verbal este o secvență dirijată, rostită în momentele multiple și variate ale existenței cotidiene, reprezentînd, probabil, cel mai uzual act verbal expresiv, și presupunînd existența a cel puțin doi participanți, ambii fiind elemente active ale actului lingvistic comportamental de tip salut.

În funcție de variabila externă de realizare a salutului (canalul de comunicare), se pot identifica:

- saluturi specifice comunicării „reale” (conversația face-to-face) vs.

- saluturi specifice comunicării mediate (prin intermediul televizorului / radioului / internetului / telefonului mobil).

În funcție de factorii lingvistici și extralingvistici specifici procesului de comunicare, formulele de salut pot fi convenționale și neconvenționale.

Sursele pe baza cărora s-au format elementele investigate le-au constituit, pe de o parte, materialul intern (modificări ale saluturilor mai vechi, convenționale, combinări inedite sau convertire funcțională a unor forme şi formule tradiţionale), iar pe de altă parte, reperele externe (împrumuturi).

Salutul cunoaște o realizare diferită de la o limbă la alta, dar și, în interiorul aceleiași limbi, de la o variantă funcțională la alta. Există, astfel, o serie de expresii verbale circumstanțiale de realizare a salutului în română în funcție de protagoniștii actului comunicativ, contextul, statutul / rolul interlocutorilor și specificul relației de comunicare. Se disting, prin urmare, saluturi ocazionate de întîlnire / plecare, zi de naștere / onomastică, nuntă, înmormîntare, sărbători religioase.

Din cauza amalgamului de comportamente comunicative (transgresarea formulelor neconvenționale de salut în contexte rezervate formulelor convenționale, mișcare izvorîtă din renunțarea indivizilor la a mai cultiva relațiile interumane ierarhice, ștergerea distanței sociale, implicit a deferenței și înlocuirea ei cu egalitarismul uniformizator), nu se mai poate vorbi astăzi despre o profesionalizare a formulelor

\footnotetext{
${ }^{14}$ „[...] utilizarea formulelor de salut este nu numai o chestiune de libertate individuală a vorbitorilor, ci şi o chestiune de conformare la normele de conduită existente în comunitatea noastră lingvistică. Regulile «etichetei lingvistice» care guvernează utilizarea formulelor de salut provin atît din limba română in se, cît și, mai ales, din acel a se cuveni, existent în codul de comportament al civilizației noastre" (Pietreanu, 1984, p. 24).
} 
de salut în funcție de parametrii diastratici și diafazici ${ }^{15}$ (probabil doar de o repartiție diatopică ${ }^{16}$ a lor). În schimb, se înregistrează o specializare a formulelor de salut pe medii de comunicare „real” / virtual. Prin urmare, analiza formulelor de salut actuale în funcție de niște variabile care altădată s-au dovedit funcționale și diagnostice pentru comportamentul adresativ românesc pe parametrul investigat nu se mai dovedește operantă. Este motivul pentru care am ales să investigăm faptele descriptiv, iar observațiile să aibă caracter particular, nu generalizator.

Ne vom ocupa, în cele ce urmează, de cîteva expresii performative specifice salutului neconvențional din limba română actuală ${ }^{17}$ „reală” și „mediată”, a căror bogăție și varietate sînt un argument pentru caracterul dinamic, ce caracterizează acest sector al lexicului contemporan ${ }^{18}$.

Prin urmare, unitățile investigate sînt formule de salut neconvenționale actuale propriu-zise sau care au devenit neconvenționale conjunctural (prin combinări, modificare lexicală și / sau semantică), avînd la bază forme de salut convenționale.

\subsection{Saluturi din comunicarea "reală”}

Interacțiunea verbală se desfășoară în conformitate cu anumite ritualuri comunicative ce reglează indicele de coeziune al perechii de adiacență salut (activ) - răspuns la salut (reactiv) ${ }^{19}$. Locutorii fiecărei comunități lingvistice dezvoltă un comportament verbal simptomatic, în cadrul căruia componentele interacționale (enunțul-stimul (salutul) + enunțul-reacţie (răspunsul la salut) tradiţionale s-au desemantizat ca urmare a întrebuințării lor repetate în construcții fixe, funcționînd ca simple mărci ale contactului social interindividual. Prototipic, enunțul de tip salut se prezintă în limba română sub forma unei sintagme fie cu centru de grup nominal (Bună dimineața / ziua / seara etc.), fie cu centru de grup verbal (Te salut).

\subsubsection{Modalități directe}

\subsubsection{Tipul „avatar” sau, „intrarea în ritual” (saluturi convenționale).}

Bună ziua, Bună seara, Bună dimineața, Noapte bună, La revedere sînt modalitățile consacrate, ritualizate de salut, neutre din punct de vedere stilistic, utilizate de locutor la întîlnire (primele patru) și la despărțire (toate). Aceste formule convenționale cunosc diverse variante (neconvenționale) obținute prin inversiune: Ziua bună, Seara bună sau prin intercalarea unui modificator și schimbarea substantivului: La bună vedere, permutările expresive fiind utilizate cu ,intenție stilistică arhaizantă și neaoșistă” (Zafiu, 2003).

\footnotetext{
${ }^{15}$ Coșeriu (1992-1993, p. 38) vorbește despre trei mari tipuri de varietate lingvistică: „varietatea diatopică (în spațiu), varietatea diastratică (între păturile sociale și culturale ale unei comunități) și varietatea diafazică (între modalitățile de vorbire determinate prin situația însăşi a vorbirii și prin elementele situației vorbirii, adică cine vorbește, cu cine, despre ce, în ce circumstanțe)".

${ }^{16}$ „Bucureştenii se salută cu «bună». Doar ardelenii mai spun «servus», dar nu toți. În Cluj, Sibiu, Banat, se foloseşte «ciau»sau «ceau». Deşi de «servus» au auzit toți românii şi unii îl folosesc chiar dacă n-au nici în clin nici în mînecă cu Ardealul, doar în zona dintre Braşov şi Covasna e folosit frecvent. În ungurime, salutul a suferit o schimbare. Maghiarii spun «servus tok» şi răspund «szia»” (participant la grup de discuții online).

${ }^{17}$ Formulele de salut neconvenționale nu caracterizează exclusiv limba română contemporană; de exemplu, există atestări istorice potrivit cărora, în perioada interbelică, locuitorii orașului Ploiești foloseau întrebarea „Ce bei?” cu rol de formulă de salut: „În Ploieştiul interbelic, era o cîrciumă la aproximativ 200 de locuitori. Aici se discutau negoțuri şi se aşteptau legături feroviare. Istoricii apreciază că de aici i se trage urbei şi renumele de oraşul lui «Ce bei ?». Ploieştenii duc povara mitului cum că sînt cam cheflii şi că le place să-şi omoare vremea prin cîrciumi încă din perioada dintre cele două războaie mondiale. Scriitorii consemnează numele de oraşul lui «Ce bei?» şi susţin că acesta se traduce prin faptul că ploieştenii nu s-ar saluta ca în alte părți ale țării, cu formulele obişnuite, ci direct cu întrebarea: «Ce bei?»” [online].

${ }^{18}$ In prezentul studiu nu ne-am propus dezvoltarea unor situații particulare de utilizare a salutului (formule de salut specifice în diferite zone rurale ale țării și în diverse medii socioprofesionale-religios, sportiv, al breslelor etc.). Acestea vor constitui obiectul unor studii extinse asupra modalităților de salut în limba română din perspectivă diacronică și sincronică. Totodată, ne propunem, cu alt prilej, o cercetare comparativă a salutului, respectiv a modalităților prin care acesta se realizează în alte limbi: romanice, germanice, slave etc.

${ }^{19}$ Liddicoat (2007, p. 106) numește cele două elemente ale unei perechi de adiacență first pair part și second pair part, subliniind că relația dintre ele este determinată de primul membru al perechii: „Therefore, a question must be followed by an answer to be heard as a completed sequence: it cannot be followed by a greeting or a farewell even though these are also possibly SPPs $[=$ second pair parts $]$ in other contexts".

${ }^{20}$ Vezi nota de subsol numărul 3.
} 
Deși codul bunelor maniere verbale recomandă utilizarea salutului La revedere la despărțire doar întrun context asimetric în ce privește distribuția rolurilor sociale, în care doar celui cu statut social superior (ca vîrstă / rang) i se cuvine să folosească formula, în practica adresativă actuală se înregistrează situații de încălcare flagrantă—din ignoranță și lipsă de preocupare din partea locutorului pentru adecvarea la situația comunicativă ${ }^{21}$ - a cutumei adresative invocate (studentul îi spune La revedere profesorului la plecare).

Aceste saluturi-avatar vor constitui resursele lexicale și semantice pentru apariția tipurilor ulterioare.

\subsubsection{Tipul „recondiționat” sau „ieșirea din ritual” (saluturi convenționale „revizuite”).}

Subtipul salutul propriu-zis (clişeizat) + precizarea alocutorului: vechile formule de salut sînt supuse unui proces de „reîmprospătare” prin alipirea unor mărci referențiale (care desemnează destinatarul).

Salutul Bună seara, România, bună seara, București! a fost consacrat de Andreea Esca, cea mai longevivă prezentatoare a unei emisiuni tv de știri din România.

Formula de salut ritualizată, neutră din punct de vedere stilistic, Bună seara, iese din ritual prin precizarea destinatarului la modul metonimic.

Bună seara, prieteni! - salutul adresat la intrarea în scenă de către solistul vocal al unei trupe de muzică rock, Cristian Minculescu.

Salutare, națiune! - salutul adresat ascultătorilor de către realizatorul unei emisiuni de radio, 13-14 cu Andrei, Andrei Gheorghe.

\section{Bună ziua / seara dumneavoastră și invitaţilor / ascultătorilor dumneavoastră!}

Considerăm că trebuie semnalată folosirea abuzivă a acestui salut în unele emisiuni de televiziune și de radio, în care invitații prin telefon ai moderatorului îşi fac intrarea în discurs printr-o precizare superfluă, în succesiune, a destinatarilor: a moderatorului, prezent în platou sau în studio, și a invitaţilor din platou / studio sau a telespectatorilor / radioascultătorilor presupuși, de acasă: Bună ziua / seara dumneavoastră și invitaților / ascultătorilor dumneavoastră!

Prezența beneficiarului nu trebuie precizată lexico-gramatical:

- prin pronumele de politețe desemnîndu-se primul component al sintagmei referențiale, i.e., moderatorul, și

- prin substantivul invitat la sg. / pl. desemnîndu-se al doilea component al referinței locutive, întrucît aceasta este implicitată în salut: salutul nu este un act verbal suspendat, monologic, iar precizarea destinatarului, ca adaos al salutului în cazul emisiunilor de tipul menționat, nu asigură activarea lui, el rămînînd, oricum, în stare de incompletitudine, actualizat doar unidimensional (sau, în cazul în care invitatul / invitaţii din platou salută și el / ei, se actualizează și răspunsul la salut).

\section{Subtipul Bună!}

De la salutul convențional Bună ziua este întrebuințată foarte frecvent forma prescurtată $B u n a ̆{ }^{22}$, un soi de echivalent al engl. $H i$, fără acoperire în română, întrucît adjectivul la feminin bună impune obliga-

\footnotetext{
${ }^{21}$ Iată care este opinia unui participant la un grup de discuții avind ca temă salutul: „[...] în toate țările civilizate din lume, salutul reprezintă egalitate, imparțialitate și respect. Nu există diferențiere în salut. Doar România, o țară extrem de umilă, își permite să aibă tipuri de saluturi, pentru a face diferența între oameni, pe scara acestora socială, financiară etc. sau rang sau clasă etc." [online].

${ }^{22}$ „Cum ar putea fi tradus acest «Bună » sau cu ce ar putea fi înlocuit? Nu aș ști să vă spun! Am avut aversiune față de el mereu. Este tot o fandoseală juvenilă, transmis și perpetuat prin ignoranța sau chiar cultivarea adulților părinți, fuduli că au copii deștepți și la modă! Cele mai potrivite saluturi mi s-au părut fie inertul lumesc «Bună ziua » al sudiștilor, fie, mai ales, formulele țărănești ardelene: «Doamne ajută» sau «Dea Dumnezeu bine», cu răspunsurile «Să ai pace» și «Să fii binecuvîntat»! Restul, emancipări occidentale într-un loc nepotrivit!” [online]. „Dacă acest «Bună » sau «Servus» se folosește de către tineri cînd salută pe toată lumea, inclusiv oamenii în vîrstă și străinii, e urît rău. De unde a apărut acest curent? Nu cred că este o problemă care să afecteze strict Ardealul, ci care afectează toată nația românească. Chit că ești ardelean, moldovean, oltean, muntean, politețea nu este normală, ci obligatorie. Probabil acum cei 7 ani de acasă, politețea sînt de modă veche; toți trebuie să fie «cool» și în «trend» cu ce văd ei la TV și în reviste de 2 bani” [online].
} 
toriu un centru de grup nominal (purtător al informației semantice), ziua / seara, el singur necomportînd vreo semnificație. Se înregistrează tendința de a-i atribui lui Bună un rol polisemantic, care concentrează semnificația tuturor celorlalte saluturi legate de diversele momente ale zilei. Această formă nespecifică și neadaptată este folosită deopotrivă de elevi și studenți pentru a se saluta între ei și, mai grav, pentru a-și saluta profesorul. Faptul că sistemul adresativ românesc este multiplu ierarhizat impune cîteva interdicții de utilizare a acestui tip de salut, al cărui loc este bine determinat de o serie de restricții funcționale în ce privește mărcile verbale ale politeții ${ }^{23}$.

\section{Subtipul (Să ai / aveți) o zi bună (și ție / tuturor)!}

Intrate în română ca urmare a calchierii unor formule englezești, Ai grijă de tine (utilizată de interlocutori la despărțire) este o adaptare a formulei Take care, iar $S a ̆$ ai / aveți o zi bună sau $O$ zi bună (și ție / tuturor)—cu marcarea alocutorului printr-un dativ sau a verbului performativ + / - subiect: Vă / $\hat{t}$ ți urez şi eu o zi bună, a formulei Have a nice day. În ultimul caz, se reiterează conținutul semantic și pragmatic de urare, remotivîndu-se, totodată, salutul, în vreme ce în formula prototipică Bună ziua, urarea nu se mai percepe. „Imitarea expresiei străine [n. n. Have a nice day] nu reprezintă un calc fidel, pentru că respectă regulile gramaticale şi lexicale româneşti: poziţia normală a adjectivului, afinitatea semantică prototipică cu substantivul. Impresia de «corp străin» nu e produsă de veritabile abateri, ci doar de faptul că noua formulă apare ca o rescriere a salutului prin excelență neutru—bună ziua" (Zafiu, 2003).

Formula cunoaște și alte dezvoltări, obținute prin substituții cvasisinonimice: Să ai / aveți o noapte liniştită / un week-end reușit!

\section{Subtipurile Hai, pa! / Bine, pa!}

$P a !^{24}$ este o interjecție-salut convențional, specifică zonei de sud a teritoriului românesc, frecventă, deopotrivă, în limbajul tinerilor și al adulților, pentru a marca finalul unei întîlniri. În uzul standard (descris mai sus), salutul menționat redă specificul unei relații interumane simetrice din punctul de vedere al statutului și rolului social, indicînd ștergerea distanței sociale dintre indivizi și codificînd relația de familiaritate (intimitate).

Precedată de interjecția predicativă hai, cu rol de mobilizator verbal înspre o acțiune, forma de salut $P a !$ îşi intensifică sensul, acela de a suspenda (temporar) întrevederea, accelerînd ruperea legăturii vizuale / auditive dintre interlocutori. Hai joacă rolul unui intensificator verbal al acțiunii descrise de semantica salutului propriu-zis și, în același timp, îi alocă un caracter ultimativ.

Secretarul de stat din Ministerul Sănătății, Raed Arafat, a declarat miercuri seară, pentru MEDIAFAX, că medicul din Cluj care ar fi insultat un pacient a avut un comportament „ieşit din normalitate", ce poate fi sancționat de Colegiul Medicilor.

Potrivit presei locale, un bolnav în vîrstă de 57 de ani, din Cluj-Napoca, diagnosticat cu cancer, i-ar fi cerut de mai multe ori medicului de familie, Ionel Mircu, bilete de trimitere, iar, la un moment dat, acesta ar fi refuzat. După ce bolnavul a vrut să se mute la alt medic de familie, a primit de la Mircu un sms cu textul: "Consideră toate concediile şi ajutoarele acordate ție şi nevestei un cadou. Ai atît de puțin timp să te mai bucuri de viață. PS. Hai, pa, nesimțitule” [online].

Anca Cojocaru, această nouă "power girl" a industriei muzicale, ne învață din proprie experiență cum să îi spunem „Hai, pa” și să mergem cu încredere mai departe, fără să ne pierdem visurile și speranțele. Astăzi, artista lansează primul său videoclip, cel pentru piesa „Hai, pa”, în regia și în fața camerei lui Alexandru Popescu, cel care ne-a adus clipuri pentru artiști ca Akcent, Connect-R, Raluka, Adrian Sina și mulți alții [online].

Tu? Cum ai petrecut? Vreau detalii picante. Te pup. Hai,pa! [online].

\footnotetext{
${ }^{23}$ Pentru o abordare contrastivă a acestui tip de salut în română și în spaniolă, vezi Mihăilescu (2008, p. 427).

${ }^{24}$ Cf. germ. pa, magh. Pá. Este un salut utilizat la despărțire „de către copii și în vorbirea cu copii sau, familiar, între adulți” (DEX); este sinonim cu La revedere!
} 
Un alt tip de salut curent, derivat prin același procedeu al combinării lexemelor din limbă, este Bine, pa! De data aceasta, salutul $\mathrm{Pa}$ ! este prefațat de adverbul bine, sintagma obținută avînd o funcție concluzivă. Bine exprimă consensul sau lipsa de consens asupra datelor furnizate de locutori pe parcursul întîlnirii, avînd scopul de a marca sfîrșitul contextului interlocuționar printr-un indice verbal suplimentar de confirmare a întreruperii contactului (pe lîngă salutul în sine).

Ambele formule noi de salut, prin adjuvanții lexico-pragmatici situaţi în poziție forte, codifică, în general, finalul tensionat al întîlnirii, intenția de întrerupere cvasidefinitivă a comunicării și, implicit, a relației dintre interactanți.

Formula Bine, pa! s-a generalizat în urma propagării ei de către prezentatorul unei emisiuni de televiziune de tip pamflet, In gura presei, transmisă la posturile de televiziune Antena 3 și, în reluare, la Antena 1, Mircea Badea, care este, totodată, și cel care a patentat-o. Inițial, el a utilizat-o pentru a-și încheia emisiunea cotidiană, în care își exprimă, într-un stil persiflant, atitudinea față de clasa politică actuală, pe care o descalifică cu orice prilej; odată recunoscut ca marcă specificatoare, termenul-salut și-a extins sfera de valabilitate, Mircea Badea transformîndu-l într-un mesaj monosemantic, însă plurivalent: acesta a postat pe Facebook două poze cu un avion (v. Figura 1), iar deasupra a scris textul (Iar) Bine, pa!, fanii prezentatorului știind să decodifice corect mesajul transmis: autorul său a plecat din țară.
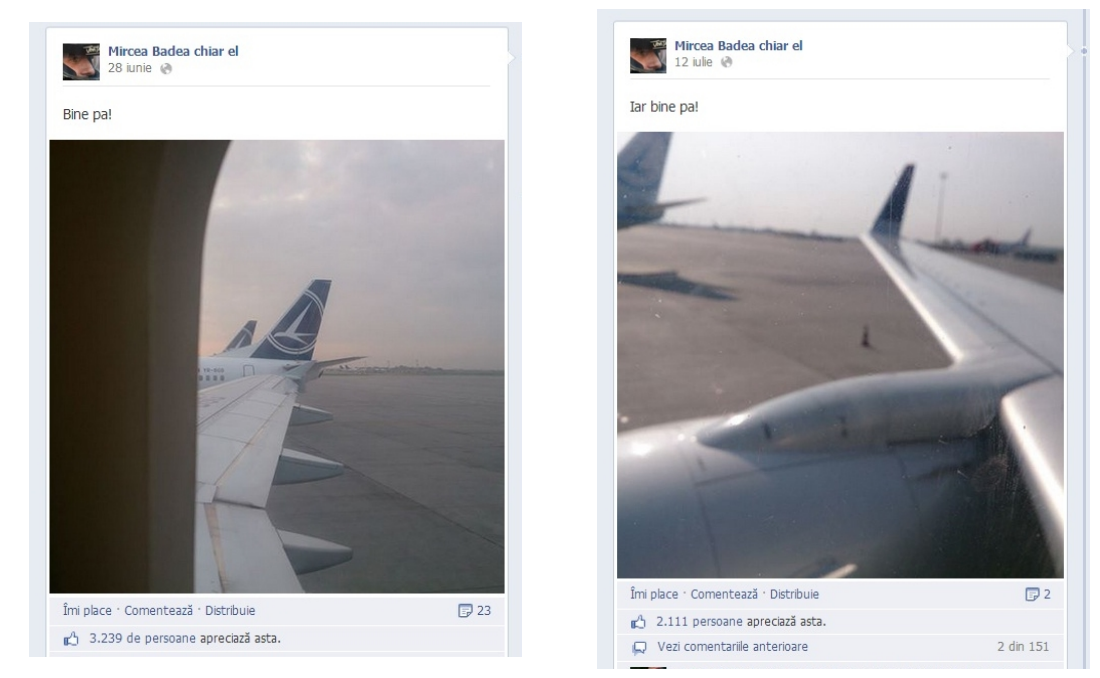

Figura 1: https://ro-ro.facebook.com/pages/Mircea-Badea-chiar-el/339817559450850

\subsubsection{Modalități indirecte}

\section{Salutul-brand din registrul cutumal monden}

Unii actori din media video și audio românească au impus, la nivelul mentalului colectiv, o serie de structuri verbale care, prin repetiție, au devenit echivalente cu formulele de salut. Din dorința de a se distinge de alți confrați de emisiuni tv sau radio din peisajul public autohton, dar şi din considerente ce țin de rating, personajele în cauză s-au folosit de anumite structuri polivalente din limba română pentru a exprima saluturi:

- formule de tip urare ${ }^{25}$ : verbul, la modul conjunctiv, din aceste saluturi-enunț se referă direct la starea destinatarului:

Să fț̦i iubiți! - enunțul prin care Radu Moraru, realizatorul emisiunii de televiziune Naşul, difuzată pentru o perioadă la postul B1, își saluta la final telespectatorii.

O atare formulă de salut a „inventat” însuși președintele României, Traian Băsescu: Să trăiți bine!, enunț ale cărui limite semantice depășesc simpla urare și proliferează sensul de slogan.

\footnotetext{
${ }^{25}$ Formulele de acest tip pot fi utilizate atît ca formule de salut, cît și drept formule de urare și de mulțumire (cf. Rădulescu, 2009, p. 401).
} 
- fraze asertive:

Trăim în România şi asta ne ocupă tot timpul! - enunțul prin care același Mircea Badea își încheie întîlnirea, seară de seară, cu telespectatorii (subtext ironic: viața în România, cu evenimentele pe care le implică, este atît de plină, încît ocupă tot timpul).

Țineți aproape! - enunțul-salut al lui Marius Tucă, fost realizator al emisiunii tv Marius Tucă Show. În acest fel își lua rămas bun, în fiecare seară, de la telespectatori (subtext: implicitarea invitaţiei de a rămîne telespectatori fideli ai emisiunii sale).

Prin larga lor circulație care le-a asigurat fixarea în „conștiința lingvistică” a locutorilor, aceste structuri noi funcționează ca mărci expresive înregistrate în nomenclatorul saluturilor emblematice românești actuale, căpătînd comportamentul (stabilitatea) saluturilor specializate pe bresle: Fir intins! (salutul pescarilor), Vînt din pupa! (salutul marinarilor), Cer senin! (salutul aviatorilor), Noroc bun! (salutul minerilor).

\title{
5.3. Saluturi din comunicarea mediată de un suport electronic
}

Accesînd diverse programe din internet, se observă circulația unor formule de salut diferite de cele din stilul comunicării orale, comunicarea mediată de computer (e-mail, skype, messenger, Facebook, bloguri) și cea prin intermediul telefonului mobil (SMS), distanțindu-se, din acest punct de vedere, de cea obişnuită.

Între caracteristicile modalităților de salut întîlnite în conversația online se înscriu următoarele:

5.3.1. prezența prescurtărilor: $n b$ pentru „noapte bună”, $b d$ („buna dimineața”), Sal (salve „salut” / „salutare"):

\author{
$\operatorname{Ev} \theta \alpha \lambda i \alpha \operatorname{Ev} \theta \alpha \lambda i \alpha$ \\ fugi \\ nb (noapte bună) \\ somn uşor \\ și bălăceală plăcută! \\ Geicu Andrei \\ îți dai seama ce varză sunt eu :)) mai varză ca varza ta din frigider \\ ms somn uşor, $\boldsymbol{n b}$ !
}

5.3.2. abundența formulelor de salut de import: calcuri / împrumuturi din engleză:

marealexandra92: ok. ne auzim. mulț înk o dată. pupik

photo.oana: npc. te pup. Bye.

Andrei Gheorghe

beeei :*

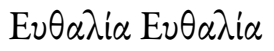

Hey :

Grup de prietene

- Hey, girls! Weekend-ul ăsta merg la o nuntă, și weekend-ul viitor, în funcție și de programul vostru, vă scot la o inghețată de ziua mea, ok? Voi cum puteți?

- Girls, am vorbit cu voi cu toate și a rămas să ne vedem sîmbătă la 4, la mall. See you there! :* [emoticon pentru „sărut”]

- bello AJjust curious, se mai ține tîrgul de adopții?

- Hello, ne întîlnim mîine la 17:15 [...].

- bello, girls are any of you interested in free zumba classes?

- salut!!!!! ce ziceți să ne întîlnim vineri [...]?

- bello, ladies, long time no see! Vă invit simbătă la ora 4 [...]. Vă aştept cu drag.

- Hello, everyone! propun o dată pt. Christmas party, ce ziceți de 27?

- bună, Aj, în legătură cu ajutorul pentru adăpostul de cîini. 
5.3.3. amestec de formule de salut românești și străine:

Grup public, „Băimăreni”

- Bună seara, de curînd am deschis un blog care se axează pe fotografie [...].

- Heyy! Ce faceți?

Mesaje private

- [aceeaşi persoană $]$ bey, cum a fost ziua ta?

Hey there! $>: D<$ [emoticon „îmbrățişare”]

La multi ani, heeei! >:D<

- [aceeaşi persoană] saluuut. da, pe site-ul ăsta mă uit

Salutaaaare. Ce să fac...

Saluuut! Ce mai faci?

- [aceeaşi persoană] bey, ce faci?

$$
\begin{aligned}
& \text { bună } \\
& \text { bello, ce faci? }
\end{aligned}
$$

- salut, cum a fost? / hello, a fost bine, am scäpat [schimb de replici]

- boo / boo back cum mai ești? [schimb de replici]

- Sal! Sunt bine, puțin ocupată. - Heei:*

- yello! mă bucur

- bya!! $c f$ ?

- bowdy. tocmai termin $c v$ work...

- bîz! [< Yahoo! Messenger „Buzz”]

- ciao, mihaela, excuse me, s-a stricat telefonul și nu am mai avut de pe ce să intru pefb

- Salutare, Ela! Multumim.

- Bună, Mihaela. Noi am ajuns cu bine inapoi în state

- sal! noi suntem bn

- ciao, ce mai faci?

- Hello, Ce maifaci?

- bei. ce faci?

5.3.4. utilizarea întrebării familiare Ce faci? cu rol de salut; maniera de a substitui salutul consacrat prin formule interogative (modalitate de salut curentă în civilizaţia anglo-americană, vezi How do you do? sau How are you?) (cf. și Duranti, 1997, p. 6), caracteristică mai ales pentru codul sociocultural românesc

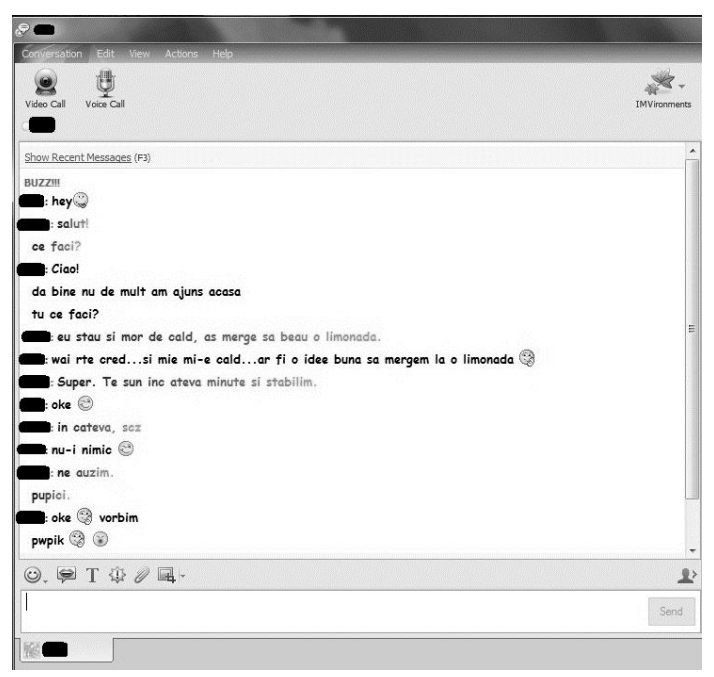

Figura 2: Fereastră messenger 
rural $^{26}$, este tot mai prezentă în deschiderea dialogului virtual:

photo.oana: da' ce faci, hei?

marealexandra92: apoi numai stau.

5.3.5. substituirea salutului verbal prin salutul non-verbal (semne iconice: emoticon-uri) (vezi Crystal, 2011, p. 23-24), vezi Figura 2;

5.3.6. opțiunea tot mai frecventă a locutorului pentru demararea conversației ex abrupto, fără prefațarea acesteia de o formă de salut:

Amicul Flavius Obeada îmi răspunde la un comentariu la el pe blog, dar nu oricum: începe prin a saluta. Am observat la el obiceiul, la fel face și pe facebook, și bănuiesc că peste tot.

Păi ce lucru ridicol e ăsta, hă-hă, păi unde se crede moșu', hă-hă, păi noi suntem pe internet aici, ce-i cu expirațiile astea, hă-hă! [...]

Eu, spre deosebire de Flavius, nu simt nevoia să salut pe internet, nici în comentarii, nici în postări și, adesea, nici măcar in e-mailuri. Nu pentru că $n$-aș percepe și-aș fi orb la conținutul semantic al salutului, ci pentru că mi-e lene, sau, mă rog, pentru că-s prost crescut. [...] [online]

\section{Concluzii}

Salutul este un act expresiv obligatoriu pentru garantarea unei comunicări reușite, absența acestuia conducînd fie la inițierea abruptă a interacțiunii, fie la crearea premiselor instaurării tăcerii (non-comunicării).

Definit, cum am văzut, ca expresie verbală a unui comportament afectiv, salutul—prin varietatea formelor sale de manifestare_,,valorează prin funcție mai mult decît prin conținut” (Zafiu, 2001, p. 183), codificind specificul relațiilor interindividuale.

Tendința tot mai accentuată, înregistrată în ultimele două decenii, de remaniere a practicii tradiționale de a saluta adecvat are repercusiuni în structura formulelor de salut.

Formele de salut verbal actuale din conversația „reală” și mediată sînt inovații (în curs de a fi adoptate) realizate la nivelul individual (discursiv) al limbajului, care, grație extinderii uzului lor şi repetabilității în contextele variate ale comunicării, au șansa să intre în sistemul limbii (istoric), prin recunoaștere și validare de către tot mai mulți vorbitori.

Din inventarul bogat al formulelor de salut din româna actuală am selectat cîteva dintre uzurile individuale inedite, veritabile mostre de inventivitate și expresivitate stilistică. Acestea, grație asumării de către tot mai mulți utilizatori și circulației lor în medii de comunicare diverse („real”: oral / scris și virtual) tind să se generalizeze în limbă sub tirania uzului. În exemplele investigate, norma convențională (congruenţa universală și corectitudinea istorică) (vezi Coșeriu, 1992-1993, p. 42) se suspendă în favoarea adecvării contextuale.

Se desprind cîteva trăsături-unele specifice, altele universale (emiterea considerațiilor asupra acestora din urmă impunînd, evident, un studiu contrastiv între situația din română și cea din alte limbi în vederea omiterii dificultăților de echivalare interculturală; cf. și Mihăilescu, 2008, p. 431)—ale românei actuale în ce privește parametrul investigat, și anume:

- bogăția și dinamismul saluturilor din registrul informal al comunicării (abandonarea treptată a formulelor de salut consacrate și propulsarea celor marcate expresiv / afectiv);

- expresivitatea, datorată spontaneității stilului și factorului afectiv;

- declinul unor saluturi convenționale (desemantizarea formulelor tradiționale), resimțite ca insuficient de expresive și supunerea lor unui proces de ne-convenționalizare (includerea lor în structuri complexe noi);

\footnotetext{
${ }^{26}$ În comunitățile rurale, localnicii inițiază conversația cu întrebări-salut de tipul: Ce faci?, Ce lucrezi?, Acolo stai?, Numai amîndouă?, Nu vă e rece / cald?, Stați de vorbă??
} 
- rapiditatea difuzării saluturilor noi, în special a celor provenite din media;

- biruința informalului și a semiformalului (forme de salut „necanonice”) asupra formalului (forme de salut standardizate), consecință a utilizării neadecvate a mărcilor de alocutivitate în româna contemporană (formalizarea raporturilor sociale ierarhic organizate este substituită de informalizarea (vezi și Pietrini, 2010, p. 264) (solidaritatea / reciprocitatea) relațiilor interindividuale);

- evoluția spre brevilocvență (reducerea cantitativă a corpului fonetic) a expresiei și spre neutralitate a conținutului;

- tendința de creare, mai ales în forumurile de discuții din mediul online, a saluturilor inedite, compozite, ludice;

- analiza formulelor de salut prilejuiește observații ce țin de evoluția relațiilor interumane și a societății românești actuale, în general.

Inventarul strategiilor verbale de inițiere, întreținere și întrerupere a dialogului din româna actuală se dovedește a fi extrem de dinamic și dispus să găzduiască noi forme adresative, într-o măsură direct proporțională cu posibilitățile limbii (combinări ale materialului existent sau inovații).

\section{Bibliografie}

\section{A. Studii}

Andrei, C. (2005). Tragerea de șireturi. Atitudini și limbaj.

Austin, J.L. (2005). Cum să faci lucruri cu vorbe, Editura Paralela 45, Pitești.

Bublitz, W. (2009). Sacks, Harvey, în Mey, J.L. (ed.), Concise Encyclopedia of Pragmatics, ediția a doua, Elsevier, p. 891-892.

Charaudeau, P. (1992). Grammaire du sens et de l'expression, Hachette, Paris.

Charaudeau, P. \& Maingueneau, D. (2002). Dictionnaire d'analyse du discours, Seuil, Paris VIe.

Cojocari, C. (2008). Semiotica și pragmatica salutului, în „Limba română”, nr. 3-4, anul XVIII.

Coșeriu, E. (1992-1993). Prelegeri și conferințe (1992-1993), cap. Competența lingvistică, supliment al publicației „Anuar de lingvistică și istorie literară”, T. XXXIII, Seria A, Lingvistică, Institutul de Filologie Română „A. Philippide”, Iaşi, p. 27-47.

Crystal, D. (2011). Internet Linguistics: A Student Guide, Routledge, New York.

Degand, L. (2009). Speech Acts and Grammar, în Mey, J.L. (ed.), Concise Encyclopedia of Pragmatics, ediția a doua, Elsevier, p. 1009-1015.

DSL = Bidu-Vrănceanu, A., Călăraşu, C., Ionescu-Ruxăndoiu, L., Mancaş, M., Pană Dindelegan, G. (2005). Dicționar de ştiințe ale limbii, ediția a II-a, Editura Nemira, Bucureşti.

Duranti, A. (1997). Linguistic Anthropology, Cambridge University Press, New York, CrossRef.

Felecan, D. (2013). Aspects of "Balkanism" Reflected in the Usage of Anthroponyms in Contemporary Romanian Public Space, în „Europa”, Magazine about Science and Art during the Transition, Nr. 12 (an VI), Novi Sad, Serbia, p. 50-65.

GALR = Guțu Romalo, V. (coord.) (2008). Gramatica limbii române, II. Enunțul, Tiraj nou, revizuit, Editura Academiei Române, Bucureşti.

Golopenția, S. (1985). L'histoire conversationnelle, /enlarged version, brochure/ Working papers and preprints, Centro Internazionale di semiotica e di linguistica, Università di Urbino, Italy.

Hobjilă, A. (2008). Comunicare și contextualizare - repere pragmatice, în „Limba română”, nr. 7-8, anul XVIII.

Liddicoat, A.J. (2007). Introduction to Conversation Analysis, Continuum, London.

Magda, M. (2004). Strategii ale discursului public - riscuri și oportunități: considerații introductive referitoare la unele disfuncţii specifice discursului public românesc actual (perspectivăpragmalingvistică), în Filip, Gh., Simionescu, B.C. (coord.), Fenomene și procese cu risc major la scară națională, Editura Academiei Române, București, p. 255-278.

Magda, M. (2007). Dialogul în comunități plurilingve: aspecte ale comportamentului mediatic alocutiv (exemplul României), în Beciu, C., Perpelea, N. (coord.), Europa și spațiul public. Practici comunicaționale, reprezentări, climat emoțional, Editura Academiei Române, București, p. 62-101.

Manu Magda, M. (2009). Indici de alocutivitate în limba română actuală. (Clasa alocutivelor interjecționale), în Pană Dindelegan, G. (coord.), Dinamica limbii române actuale. Aspecte gramaticale și discursive, Editura Academiei Române, București, p. 459-490.

Manu Magda, M. (2010). Adresarea, mss.

Mihăilescu, A. (2008). Salutul in română și în spaniolă. Perspectivă interculturală, în Pană Dindelegan, G. (coord.), Limba română. Dinamica limbii, dinamica interpretării. Actele celui de al 7-lea Colocviu al Catedrei de Limba română (7-8 decembrie 2007), Editura Universității din București, București, p. 425-432.

Necula (Zvirid), R.-M. (2012). Actele verbale expresive în limba română.

Nienhaus, S. (2009). Il saluto nella comunicazione interculturale. 
Pietreanu, M. (1984). Salutul în limba română. Studiu sociolingvistic, Editura Științifică și Enciclopedică, București.

Pietrini, D. (2010). «Salve! Un saluto veloce e tutti». Riflessioni sul sistema dei saluti nell'italiano contemporaneo, în Contributi difilologia dell'Italia Mediana, direttori: U. Vignuzzi, E. Mattesini, vol. XXIV, Editoriale Umbra, Città di Castello, p. 233264.

Pleșu, A. (2006). Comèdii la porțile Orientului, cap. Tutuiala, Editura Humanitas, București.

Proost, K. (2009), Speech Act Verbs, în Mey, J.L. (ed.), Concise Encyclopedia of Pragmatics, ediția a doua, Elsevier, p. 995-1000.

Rădulescu, A. (2009). Exprimarea mulțumirilor în română, în Zafiu, R., Stoica, G., Constantinescu, M.N. (eds.), Limba română: teme actuale. Actele celui de al 8-lea Colocviu al Catedrei de Limba română (București, 5-6 decembrie 2008), Editura Universității din București, București, p. 395-403.

Sabatini, F. \& Coletti, V. (eds.) (2005). Il Sabatini Coletti 2006. Dizionario della lingua italiana, Rizzoli/Larousse, Milano. Searle, J.R. (1972). Les actes de langage, Hermann, Paris.

Sperber, D. \& Wilson, D. (1996). Relevance: Communication and Cognition, ediția a doua, Blackwell, Oxford. Zafiu, R. (2001). Diversitate stilistică în româna actuală, Editura Universității din București, București.

Zafiu, R. (2003). Saluturi noi, în „România literară”.

\section{B. Surse}

http://adevarul.ro/locale/ploiesti/foto-ploiesti-orasul-ce-beib-povestea-locului-oamenii-nu-saluta-buna-ziua1_527d243bc7b855ff56d23b75/index.html

http://audiopub.wordpress.com/2013/06/18

http://cluj-napoca.zilesinopti.ro

http://www.crestinortodox.ro/forum

DEX $=$ http://dexonline.ro

http://www.gandul.info/stiri

http://www.medierenet.ro/2012/11/22

http://nemaipomenit.wordpress.com/2011/01/24/salutul-la-romani

http://www.parinti.com

http://polimedia.us/trilema/2010/formule-de-salut

http://www.realitatea.net

http://stirileprotv.ro 